the $12 \frac{1}{2}$ gal. which I have mentioned represents 25 divided by 2 . I am confident that taking herds of the same dairy or dual-purpose breeds, there has been improvement in milk yields brought about by the skill of the breeder aided by milk recording, but it is, I think, quite certain that the increase in milk yields that has taken place in perhaps the majority of well-managed herds, during the last 50 or even the last 20 years, has mainly been due to the other causes I have mentioned. I am, nevertheless, hopeful that in the course of the next 50 years, improvements in the selection of breeding stock, especially bulls, and the methods of using them will exert a much greater proportional effect than breeders have been able to secure in the past.

\title{
REFERENCES
}

Board of Agriculture (1 895). Agric. Statist. 1894 .

Board of Agriculture (1912). The Agricultural Output of Great Britain, 1908. [Cd. 6277.] London: H.M. Stationery Office.

Department of Agriculture for Scotland (1948). Agric. Statist., Scot., 1939-44, part I.

Department of Agriculture for Scotland (1950). Agric. Statist., Scot., 1939-44, part 2.

Edwards, J. (1950). F. Fmrs' Club, part 6.

Milk Marketing Board (undated). Nat. Milk. Rec. Ann. Rep. (E. \& W.), 1949.

Ministry of Agriculture and Fisheries (1941). Agric. Statist., Lond., 74, part 1.

Ministry of Agriculture and Fisheries, Department of Agriculture for Scotland and Ministry of Agriculture, Northern Ireland (1948). Agric. Statist., U.K., 1945, part I.

Ministry of Agriculture and Fisheries, Department of Agriculture for Scotland and Ministry of Agriculture, Northem Ireland (1949). Agric. Statist., U.K., 1939-40 to 1945-6, part 2.

Ministry of Agriculture and Fisheries, Department of Agriculture for Scotland and Ministry of Agriculture, Northern Ireland (1950). Agric. Statist., U.K., 1946-7, part 1.

\section{Culinary Uses of Milk}

\section{By Mary Andross, Glasgow and West of Scotland College of Domestic Science,} r Park Drive, Glasgow, C. 3

A pint of average milk supplies about $340 \mathrm{Cal}$., $\mathrm{I} 8 \mathrm{~g}$. protein, $680 \mathrm{mg}$. calcium, $0.6 \mathrm{mg}$. iron, 600 i.u. vitamin $\mathrm{A}, 0.2 \mathrm{mg}$. aneurin, $0.8 \mathrm{mg}$. riboflavin, $0.4^{8} \mathrm{mg}$. nicotinic acid, $6 \mathrm{mg}$. ascorbic acid, and $\mathrm{i} 2 \mathrm{i}$.u. vitamin $\mathrm{D}$. The proportion this represents of our daily requirement is shown in Fig. $r$. A pint of milk would therefore be an excellent addition to our diet for protein, calcium, vitamin $A$ (summer only) and riboflavin. It is, on the other hand, poor in calories, in iron, and in nicotinic acid. The amount of ascorbic acid is variable and depends on the amount of oxidation. Calories, iron and aneurin are easily supplied at the present time by bread. Nicotinic acid is more difficult to obtain in adequate amounts during the present shortage of meat, although fish is a good source, and potatoes are a better source per $100 \mathrm{Cal}$. than is bread.

Le Gros Clark (1947) showed that the expectation of life is highest if the proportion of calories derived from bread and potatoes is less than $50 \%$. Cuthbertson (1942), in his work on wound healing, showed the value of animal protein, and concluded that the virile races of the world are the animal-protein eaters (Cuthbertson, 1950). We must, therefore, aim at keeping up our animal-protein intake. The lowest minimum adult requirement is $25 \mathrm{~g}$., and the aim of this paper is to show how this value can be maintained by using raw or processed milks. 
As a source of animal protein, milk is not expensive (Fig. 2). The standard used for meat in constructing Fig. 2 was stewing steak. Although meat is cheaper at the present controlled price, eggs are more expensive than milk and cheese, and fish and bacon

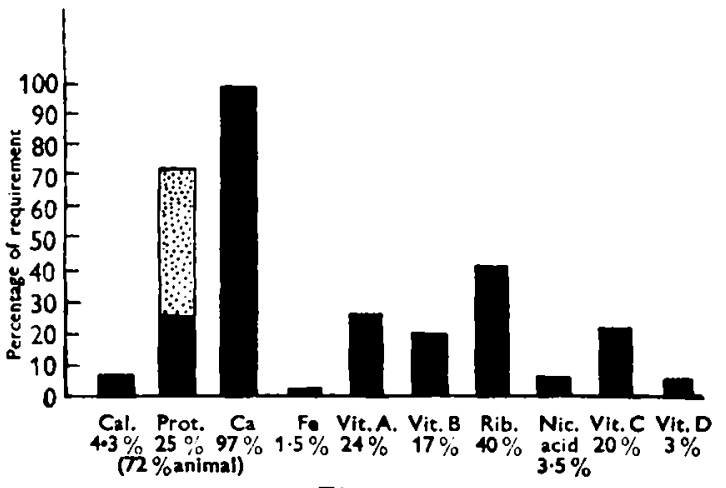

Fig. I

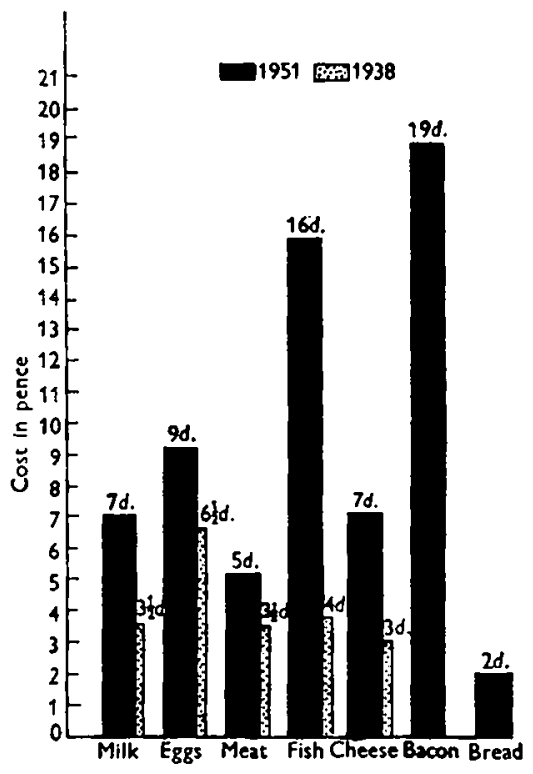

Fig. 2

Fig. 1. Percentage of daily requirement of nutrients supplied by 1 pt. of milk.

Fig. 2. Cost of $25 \mathrm{~g}$. animal protein as milk, eggs, meat, fish, cheese and bacon.

are very dear. The present cost of bread protein is shown for comparison. Rabbit at $6 s . / \mathrm{lb}$. makes our protein requirement cost $3 s .6 d$. and chicken at $\mathrm{I} 2 \mathrm{~s} .6 \mathrm{~d}$./lb. gives it the prohibitive value of $7 s$. Iod. It is interesting to compare the cost of protein requirement in 195 I with the cost in 1938. Bacon, unfortunately, was not included in our 1938 survey (Andross, I94I), but it can be seen that the cost of fish is treble, and that of cheese and milk double, the 1938 value. Meat and eggs have increased by less than one-third, presumably because the price is subject to control (Andross, 1941).

But rationing also makes us depend on milk. It is shown in Fig. 3 that we require about $\frac{3}{4}$ pt. to satisfy our animal-protein requirement, $\frac{2}{3} \mathrm{pt}$. to satisfy our calcium requirement, and I pt. to satisfy our riboflavin requirement, despite our allowances of other protein foods. The further aim of this paper is to determine how much of this quantity of milk can be used in cooking. Many adults do not drink milk, and still persist in regarding it as a beverage rather than as a food.

\section{Milk in cooking}

Milk in cooking is used in baking, in making white and cheese sauces, in the preparation of pouring and baked custards, milk puddings and cream soups. It is also used in preparing curds or junkets, milk jellies and ice-creams. In Fig. 4 the quantity of milk included in one helping of some of these products is shown, and compared 
with that consumed in beverages. Incorporation of milk in cooked products is shown to be limited. Rice pudding and other milky puddings, baked custards, cheese sauce and creamed soups add considerably to the animal-protein content of the diet.

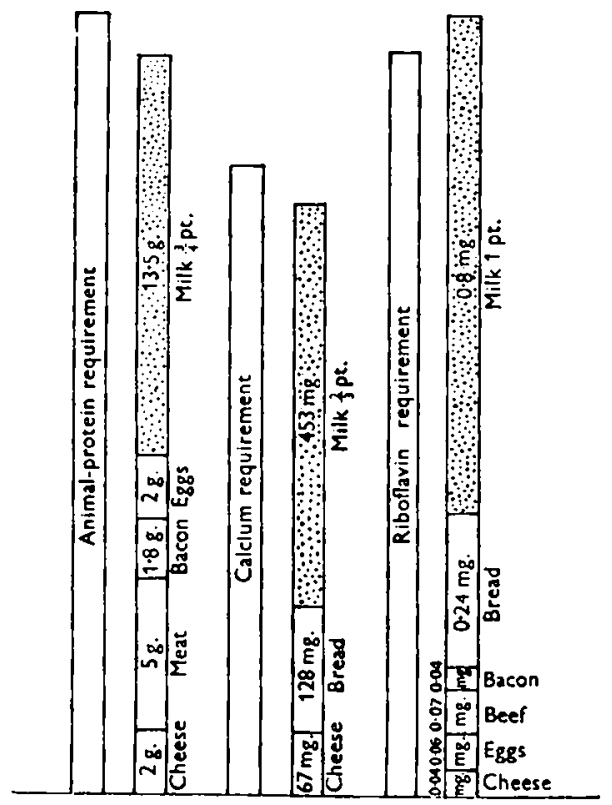

Fig. 3. Proportion of daily requirement of protein, calcium and riboflavin supplied by rations, and amount of milk which must be consumed to make up requirement.

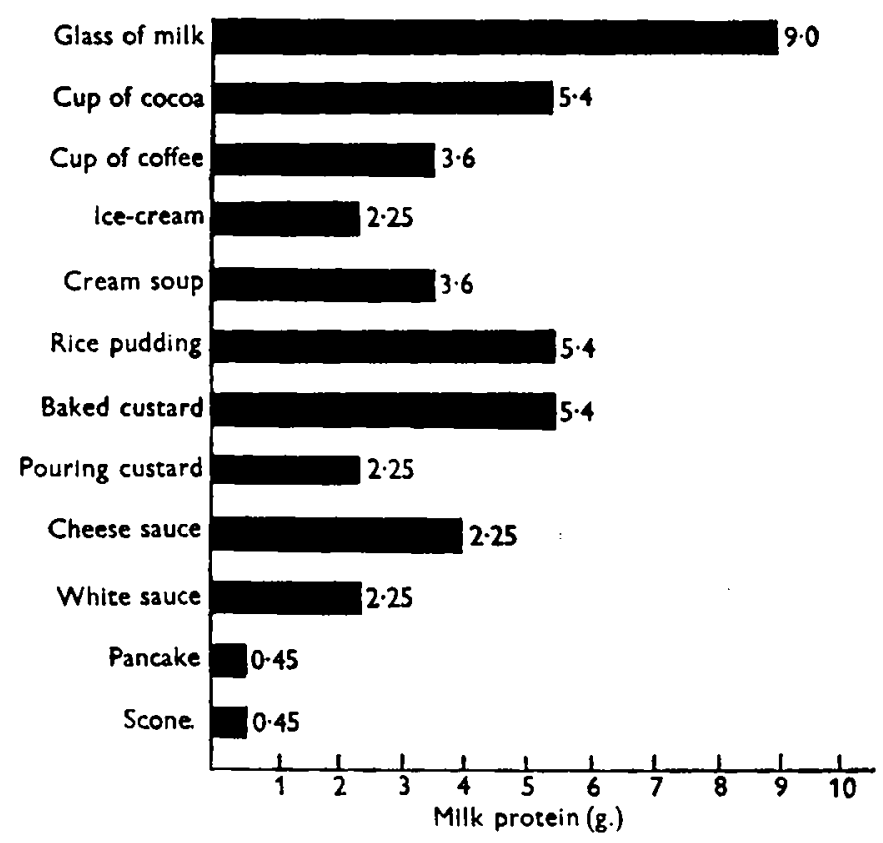

Fig. 4. Amount of milk protein in a helping of various dishes. 
Otherwise the amount of milk that can be used in cooking seems somewhat low, especially in baked products. Nevertheless, the greatest care must be taken in altering standard recipes since the product must have its normal appearance and flavour, for bizarre combinations and unfamiliar types of food are almost certain to be rejected. The easiest way of increasing the milk intake is by the consumption of beverages that are normally taken once or twice daily.

The addition of milk to soup is sometimes followed by curdling and spoilage; this is particularly marked with tomato soup. Our results have not always been consistent, but we have found that it is safer to add cold milk to hot soup. Milk is altered by heating so that it curdles more easily and its $\mathrm{pH}$ is lowered by acid production, particularly if the milk is not fresh. Addition of a trace of sodium bicarbonate will prevent the curd. Slow heating in a double boiler also tends towards curdling. The isoelectric point for casein is at $\mathrm{pH}_{4} \cdot 6$, and this is the point at which curdling occurs in a soup. If sufficient acid is added to lower the $\mathrm{pH}$ below $4^{\cdot 6}$, the casein may form soluble salts so that the curd disappears. 'This explains the preparation of uncurdled milk shakes with fruit juices. We have found that the safest way of making tomato soup is to prepare a sauce with flour and butter or margarine and either milk or tomato puree, and then to add the other ingredients. The flour forms an additive colloid with the casein and curdling does not take place.

Fish and vegetables can be baked in milk. Again the product can be spoilt by curdling which, however, can be prevented by addition of sodium bicarbonate. Salt fish is more likely to cause curdling than fresh fish. A favourite Scots dish is findon haddock poached in milk. We have found that the best way to prevent curdling in such fish dishes is to add the milk gradually during cooking. This prevents the precipitation of casein by overheating and decreases the amount of lactose caramelized. The amount of milk protein for one person from such a dish is $2 \cdot 25 \mathrm{~g}$. per helping.

Some vegetables always cause coagulation and therefore cannot be cooked in milk. Peas, carrots, beans and asparagus are examples. Cauliflower, cabbage and spinach do not cause coagulation. Although some vegetables are slightly acid the precipitation in this instance is thought to be due to the tannin and salt content rather than to the acidity. The tannin causes denaturation of the colloidal calcium caseinate and renders it more sensitive to the ions in the vegetable juices (Lowe, 1932).

Another method of using milk in cooking is in junkets in which milk is coagulated with rennin. Flavoured junket powders are now available, and junkets can also be sprinkled with chocolate or spice. From a nutritive point of view junkets have the same value as milk. A helping would be equivalent to from I gill to $\frac{1}{2} \mathrm{pt}$. of milk, i.e. 4.5-9 g. protein.

Milk jellies are made by setting milk with flavoured gelatin. Care must be taken to cool the gelatin after dissolving it and before adding the milk, otherwise the milk will curdle. Setting in a refrigerator is an advantage. If solid gelatin is used it must be swollen first in cold water; hot water is then added.

In the preparation of pouring custard in a double boiler, quick-boiling water in the outer jacket gives a thickening point at $87^{\circ}$ and curdling at $90^{\circ}$. Slow-boiling water gives a thickening point at $82^{\circ}$ and curdling at $87^{\circ}$. The interval between thickening 
and curdling is, therefore, greater with slow boiling, which allows the cook a greater margin of safety.

Baking custards show a fall in temperature just before setting. The setting temperature varies with the recipe but a mixture consisting of one egg, one cup of milk and one tablespoonful of sugar will set at $87^{\circ}$. The only method of obtaining such a low temperature in an oven is to cook the mixture in a vessel contained in a basin of water (Andross, 1940).

Evaporated milks. Processed milks can be used to advantage in cooking. Excellent dishes can be made with condensed milk. This product contains $40 \%$ sugar so no sweetening is required. Lemon-meringue pie can be filled with a tin of sweetened condensed milk, two eggs and the juice and rind of two lemons instead of the usual

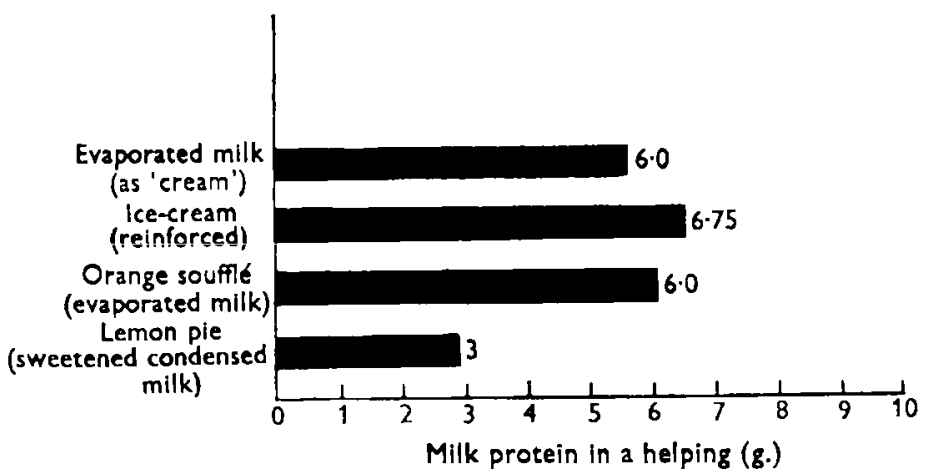

Fig. 5. Some ways of using evaporated milk and sweetened condensed milk to increase protein intake.

cornflour filling. Such a pie will supply six persons, and provide them with $3 \mathrm{~g}$. protein each in addition to that in the normal recipe. A reinforced ice-cream for invalids can be made by freezing a tin of sweetened condensed milk and a tin of evaporated milk. A helping would supply the patient with $6 \cdot 7 \mathrm{~g}$. protein. Serving unsweetened evaporated milk with sweets is a good way of using evaporated milk. This will be more favoured in Scotland where it is customary to serve milk or cream with desserts. Half a gill can be consumed in this way, equivalent to $6 \mathrm{~g}$. protein. Unsweetened condensed milk makes excellent cold souffés. No egg is required. One tin of evaporated milk beaten until it is just setting with an orange jelly dissolved in orange juice sets in half an hour. This serves six persons giving each $6 \mathrm{~g}$. additional protein (Fig. 5).

Dried milks. We have also experimented with dried milk, both skim and full cream, in order to find how much of each could be added to established recipes to increase the protein value. Scones, cakes and sauces were tested. Jack \& Haynes (I95I) reported a preference among boys for bread containing up to $14 \%$ milk solids. This meant an increase in protein intake of $8 \mathrm{~g}$. daily.

In our first experiments we used dried milk in place of raw milk in making scones. Penetrometer tests were made for texture, and density tests for lightness. A flavour score was also taken. The results, which are shown in 'Table $I$, indicate that there was little difference in the product when dried milk was used instead of raw milk in scone 
baking. They also showed that there was little or no advantage in reconstituting the dried milk before using it. In fact, unreconstituted milk mixed dry with the flour gave a lighter scone with a higher flavour score than reconstituted milk. The texture of the scones appeared to be slightly better with raw milk.

Table $\mathrm{I}$. The effect of using dried milk (as a powder and also when reconstituted) as a substitute for raw milk in the baking of scones

\begin{tabular}{lccc} 
& \multicolumn{3}{c}{ Texture and density of scones } \\
$\begin{array}{c}\text { Penetrometer } \\
\text { measurement } \\
\text { Type of milk used }\end{array}$ & $\begin{array}{c}\text { Density } \\
(\mathrm{g} . / \mathrm{ml})\end{array}$ & $\begin{array}{c}\text { Flavour } \\
\text { score }\end{array}$ \\
Normal (raw) & 6.7 & 0.012 & 1 \\
Reconstituted dried & 6.5 & 0.020 & 2 \\
Dried mixed with flour; water added & 6.6 & 0.011 & 1
\end{tabular}

Table 2. The effect of increasing the proportion of dried milk used in the baking of scones

$\begin{array}{cccc}\begin{array}{c}\text { Amount of } \\ \begin{array}{c}\text { dried milk added } \\ (\mathrm{g} . / \mathrm{I} \text { lb. flour })\end{array}\end{array} & \begin{array}{c}\text { Penetrometer } \\ \text { measurement } \\ (\mathrm{cm} .)\end{array} & \begin{array}{c}\text { Density } \\ (\mathrm{g} . / \mathrm{ml} .)\end{array} & \begin{array}{c}\text { Flavour } \\ \text { score }\end{array} \\ 0 & 0.70 & 0.012 & 1 \\ 3.5 & 0.55 & 0.014 & 2 \\ 5.25 & 0.55 & 0.016 & 2 \\ 7.0 & 0.50 & 0.020 & 4\end{array}$

In our next set of experiments, $3.5 \mathrm{~g}$. (one teaspoonful), $5.25 \mathrm{~g}$. (one and one-half teaspoonfuls) and $7 \mathrm{~g}$. (two teaspoonfuls) of dried milk were added to the normal scone mixture using $\frac{1}{2} \mathrm{lb}$. flour. The same tests were performed as in the first set and the results are shown in Table 2 . The scones became progressively denser as the proportion of dried milk was increased. Texture was only slightly affected. A high flavour score went to the mixture containing $5.25 \mathrm{~g}$. dried milk because the high protein content gave the scones an attractive brown colour. The addition of $7 \cdot 0 \mathrm{~g}$. dried milk would be tolerated, but a greater quantity was detectable in flavour and was therefore disliked; also the scones felt very heavy. Our conclusion from these experiments is that $2.5 \mathrm{~g}$. protein as dried milk can be added to scones containing $3.6 \mathrm{~g}$. protein from raw milk, and the product still remain acceptable to the consumer. This is an increase in the content of milk protein of $69 \%$.

Cakes were also tested. Although it is generally accepted by experts that the addition of milk spoils a sponge cake, butter sponge was made containing three eggs, $6 \mathrm{oz}$. flour and $6 \mathrm{oz}$. sugar. If dried egg was used, $3.5 \mathrm{~g}$. full cream, and $7 \mathrm{~g}$. skim milk powder could be added without causing spoilage. If whole egg were used, double these quantities could be added. The penetrometer value fell as the amount of dried milk increased in the cakes. From these results it can be concluded that dried milk can be added to cakes in amounts that will increase the animal-protein value by about $10 \%$.

The viscosity in sauces was found to increase with the amounts of dried milk added 
but the amount of flour could be reduced to give the proper texture. A distinct preference in flavour score seemed to be for the sauce to which $3.5 \mathrm{~g}$. of dried milk had been added per $\frac{1}{2}$ pt. raw milk. This is an increase in animal-protein content of $13 \%$ (Fig. 6).

With rice puddings we found that $7 \mathrm{~g}$. dried milk could be added per pint of milk without spoiling the flavour score. The best flavour score was made by an I I \% increase in animal protein (Fig. 6). It is interesting to compare these results with the experiments of Morse, Davis \& Jack (I950) who found it possible to add double this amount to white sauces. Their results for cakes were also higher.

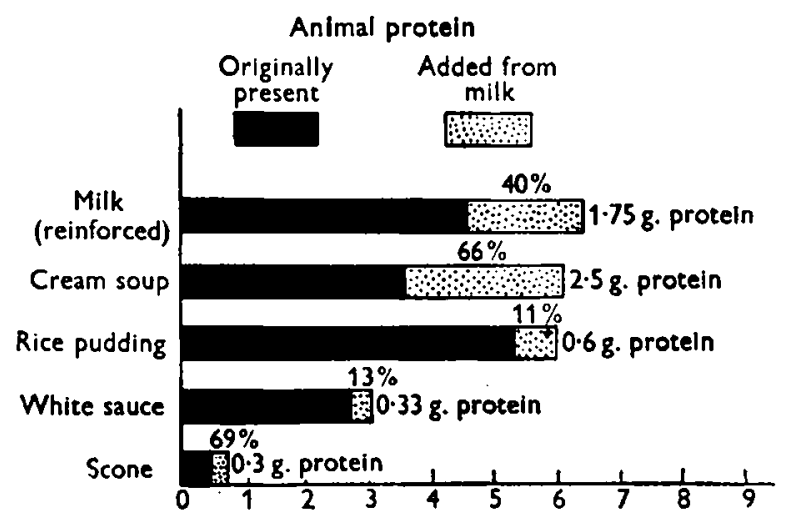

Fig. 6. Amounts by which intake of animal protein from a helping can be improved by adding dried milk to various dishes.

It is said to be possible to increase the protein content of a soup to a protein content of $9 \mathrm{~g}$. per helping by the addition of dried milk (Fig. 6). This high value was not found acceptable by our tasting panel. They discarded soups having more than $6 \mathrm{~g} . /$ $0.5 \mathrm{pt}$. or helping. This is a $66 \%$ increase in animal protein, and is equivalent to $7 \mathrm{~g}$., or two teaspoonfuls, of dried milk. This would seem to be a large amount per helping, but the full flavour of the soup masks the flavour of the milk. Only cream soups with a strong flavour like celery will carry this amount.

Dried milk can be used in making icing, 'whipped cream' fillings for cakes, chocolate trinidads and the like, all of which increase the protein content of the diet. Care must be taken to use such uncooked products without delay, since dried milk is not bacteriologically sterile, and the bacteria in it will multiply in the presence of water unless they are killed by cooking.

One ice-cream recipe in common use employs $7 \mathrm{~g}$. dried milk per helping. It contains, therefore, $2.5 \mathrm{~g}$. animal protein. This is also the animal-protein value of ice-cream from raw milk. We found the texture unsatisfactory when we attempted to increase the proportion of dried milk. Dried milk can also be used in hospital diets where reinforcement of the diet is necessary by high-protein feeding. Such diets are now used in treatment of shock following accidents, burns and serious operations. They are also used in treatment of patients acutely ill with fevers, where consumption of food is greatly curtailed (Simmonds, 1948). The proportions in which dried milk is 
used in such diets is $2 \mathrm{oz}$. dried full cream $/ 40 \mathrm{oz}$. milk. Where the diet must be low in fat, $8 \mathrm{oz}$. dried skim milk are added to $40 \mathrm{oz}$. water.

\section{Loss of nutritive value}

The losses in the nutritive value of milk as a result of different types of processing were studied by Kon (1945). His main findings are shown in 'Table 3. Unsweetened evaporated milk suffers the greatest loss because of the high temperature at which it is processed. Evaporated milks and dried milks are usually made in the summer at the

Table 3. Typical losses sustained by milk when processed

\begin{tabular}{|c|c|c|c|}
\hline \multirow[b]{2}{*}{ Type of milk } & \multicolumn{3}{|l|}{ (Kon, 1945) } \\
\hline & $\begin{array}{c}\text { Biological } \\
\text { value of } \\
\text { protein } \\
(\%)\end{array}$ & $\begin{array}{c}\text { Vitamin } \\
\mathbf{C} \\
(\%)\end{array}$ & $\begin{array}{c}\text { Vitamin } \\
B_{1} \\
(\%)\end{array}$ \\
\hline $\begin{array}{l}\text { Spray dried } \\
\text { Roller dried }\end{array}$ & .5 & $\begin{array}{l}20 \\
30\end{array}$ & $\begin{array}{l}10 \\
\text { ? } 10\end{array}$ \\
\hline $\begin{array}{l}\text { Condensed sweetened } \\
\text { Evaporated }\end{array}$ & Slightly decreased & $\begin{array}{l}15 \\
60\end{array}$ & $\begin{array}{r}5-10 \\
30-50\end{array}$ \\
\hline
\end{tabular}

peak periods of milk production when the cows are at pasture so they are often richer in vitamin $A$ and vitamin $D$ than raw milk. The nutritive value of lactalbumin may be diminished by heating, probably owing to changes taking place in the linkages between the amino-acids which render them less susceptible to enzymic hydrolysis (Davis, Rizzo \& Smith, I949). Just before milk reaches boiling-point it becomes creamy like a custard, owing to setting of the lactalbumin envelopes around the fat globules. Further heating causes these to burst, when portions of them fall to the bottom of the pan, and other portions float to the top of the milk as skin. The albumin on the bottom of the pan is in a cup formation visible to the naked eye. It is very apt to char and give the product a burnt taste. For this reason milk should always be heated in a double boiler. This albumin occludes some of the calcium which is therefore lost. If the skin is discarded, as it often is, fat, protein and calcium are also lost. Skin should therefore be consumed where possible, e.g. it should not be skimmed off a milk pudding and discarded. The creamiest milk puddings are those cooked in the oven where the milk has been kept just below boiling-point (Andross, 1939). Overcooking, particularly at a high temperature, causes caramelization of the lactose, and the product assumes a brownish grey colour. The lactic acid produced may cause curdling. Casein is precipitated by prolonged heating above boiling-point.

Cream. Cream is an emulsion of fat in water, for which caseinogen and calcium caseinogenate are said to be the main emulsifying agents, but lactalbumin is probably also concerned in this process. When cream is whipped a temporary froth is formed by the protein. The air in the froth is surrounded by semi-solid fat clusters. These air-in-fat clusters form a network which becomes more stable as the clusters touch each other. The best whip is obtained if the fat is in a semi-solid condition. If cream is boiled or cooled it will not whip because the protein has been coagulated or precipi- 
tated. Cream with a fat content of less than $30 \%$ will not whip to a permanent emulsion since skim milk will separate from it on standing. Newly separated or newly pasteurized cream will not whip unless it is allowed to stand for $3 \mathrm{hr}$. Cream where acidity has developed, as in risen cream, whips more easily. Raw cream is better for whipping than pasteurized cream but its bacterial content may be high. The best whipping temperature is $7-8^{\circ}$.

Cream contains vitamin $A$ and vitamin $D$ in greater concentration than does milk. It contains an easily assimilated fat and is a food of high caloric value. Because it is so appetizing, its psychological value in food preparation is very great and for the past Io years British cooks have been attempting to prepare substitutes for cream. Highclass cooking is impossible without it, but a small quantity of it goes a long way in making a dish look attractive. We could use dried skim milk in baking to make a small amount of cream available for decorative purposes. This would certainly raise the standard of cooking in the British Isles.

\section{SUMMARY}

Under present conditions the British people require I pt./day of milk to reach their requirement of $25 \mathrm{~g}$. animal protein, $670 \mathrm{mg}$. calcium and $\mathrm{I} \cdot 24 \mathrm{mg}$. riboflavin.

Methods of prevention of curdling in soups, and fish and vegetable dishes made with milk have been determined.

The amounts of animal protein provided by foods made with milk have been studied with particular reference to the contribution made by the milk.

The making of jellies and junkets has been investigated to find the best methods for their preparation.

Some methods of using condensed milks have been suggested, and the valuable amounts of animal protein they can contribute to the diet have been shown. The amounts of dried milk which can be added to certain products without spoilage have been determined.

\section{REFERENCES}

Andross, M. (1939). F. Soc. Chem. Ind., Lond., 58, 252.

Andross, M. (1940). Chem. Eீ Ind. 59, 449.

Andross, M. (194I). Chem. Eீ Ind. 60, I 76.

Clark, Le G. (1947). Feed the Human Family. London: Sigma Books Ltd.

Cuthbertson, D. P. (1942). Lancet, 242, 433.

Cuthbertson, D. P. (1950). F. Sci. Food Agric. 1, 35.

Davis, R. M., Rizzo, P. \& Smith, A. H. (1949). Ұ. Nutrit. 37, I 15.

Jack, E. L. \& Haynes, V. M. (195I). Food Res. 16, 57.

Kon, S. K. (1945). Y. R. Soc. Arts, 93, 122.

Lowe, B. (1932). Experimental Cookery, p. 267. New York: Wiley.

Morse, L. M., Davis, D. S. \& Jack, E. L. (1950). Food Res. 15, 200.

Simmonds, R. M. (1948). Nutrition, Diet and Catering, I I February 1950. 